\title{
Corporate Governance Research Opportunities in Nigeria: A National Development Issue
}

\author{
Rosemary O. Obasi \\ Department of Accounting, Benson Idahosa University, Benin City, Nigeria \\ robasi@biu,edu,ng, rossyobasi31@gmail.com
}

Keywords: Corporate governance, corporate governance research, governance policy making

\begin{abstract}
This paper presents a number of research opportunities in corporate governance in Nigeria. Corporate governance has come along with changes in Nigeria regulatory framework for financial reporting and corporate governance code during recent years. The researcher identified some important areas where research can help advance our knowledge and provide relevant information for policy makers. These research areas include audit firm governance, corporate level of compliance on corporate governance; public sector code of governance; adoption of not-for-profit governance code by such organisations in Nigeria. The research questions that were raised are of global interest, but the Nigeria environment provides some distinctive natural experimental settings to address these questions.
\end{abstract}

\subsection{Introduction}

Corporate governance is balancing of the multiple interests of an entity's stakeholders, such as, shareholders, management, customers, employees, government, financiers, suppliers, etc [1]. Other researchers defined it as how investors get the managers to give them back their money [2].

Corporate governance has been identified as a crucial element in ensuring that companies thrive even in the face of economic recession. Recessions lead to greater advocacy for transparency or greater accountability in corporate governance, with activists challenging decisions of Board of Directors and putting greater pressure on management for performance. Also, strengthening of corporate governance leads to enhanced resource utilization across private and public sectors [3]. $\mathrm{He}$ further buttressed that good corporate governance practice in times of recession would enhance efficiency in, and ultimately greater resource allocation across the economy, thus leading to a faster route out of the economic recession.

Studies have shown that recession or financial crisis can be to an important extent attributed to failure and weaknesses in corporate governance arrangements. Thus, there is inverse relationship between performance of corporate governance and economic growth, indicating that most of the advances witnessed in the field of corporate governance have been at the cusp of economic recessions $[3,4]$. A study reviewed Japan's corporate governance patterns as responsible for the country's export success and for the decline of United State manufacturing from1960s onwards [5]. The said study finds that corporate governance patterns carry a typical characteristic of a spatial fix in Japan sense, that is, it can switch a crisis to another country or defer the crisis to the future.

The current recession suggests a need for the study to raise questions that will enable researchers to re-examine the adequacy of corporate governance principles in the key areas in order to judge whether additional guidance and or clarification is needed. Thus, the purpose of this article is to present a number of research opportunities in corporate governance that come along with the changes in Nigeria regulatory framework landscape.

Despite the fact that the issues addressed in this article are of global interest, the Nigerian environment has some unique features that allow studying these questions. As a starting point, this paper makes use of the insights of the Demaki [6] in the article 'proliferation of codes of corporate governance in Nigeria and economic development'. In particular, Demaki's study provided background information about the proliferation of corporate governance codes among industries regulators that influence the corporate governance environment and business risk; giving an overview 
of corporate governance issues in Nigeria; illustrated the issues of proliferation of corporate governance codes, the disparities in the different codes; and concluded with suggestions for harmonized corporate governance code for companies, government ministries, departments and agencies for the economic growth and development of Nigeria. Also, this study builds on the works of Akinkoye and Olasanmi [7]. In their study, they evaluated corporate governance practices among selected non-financial quoted firms across industries. They analysed the level of compliance with 2003 code of best practices in Nigeria by providing an overview of the major changes that have occurred in Nigeria between 2003 and 2010. Thus, this study, however, reviewed their studies by providing an overview of the major changes that have occurred in Nigeria since their study was published and outlines how the changes have shaped current and future discussions about governance, accounting and auditing, and the resulting implications and opportunities for corporate governance research. Our main conclusions are the following:

Firstly, Demaki strongly emphasized the proliferation of corporate governance code in Nigeria. At that time there was no Nation-wide regulatory framework for the Nigerian heterogeneous capital market. Currently, there is such a central regulatory framework, which has resulted in the de facto development of an integrated national code.

Secondly, since 2003, we have witnessed increasing globalization of capital markets. This has resulted in an increasing demand for global accountability and governance standards. The question is whether the different codes are sufficient to ensure high-quality financial reporting and good governance if the underlying institutional structures are still mainly determined by national forces. This seems doubtful because, in addition to national stability, the primary institutional features of financial reporting and auditing relate to governance and internal control, enforcement, the legal system, and regulatory agencies such as securities regulators and public oversight bodies such as Financial Reporting Council of Nigeria (FRCN).

Thirdly, the new Nigeria scenery is characterized by increasing code. Natural questions that follow are: How effective are these codes? What are the alternative forms of regulation, and under what circumstance will they work? Why will they work under these circumstances? DO the benefits outweigh the costs? What are, if any, the unintended consequences of different codes? Research can play an important role in addressing these questions.

Fourthly, this study makes a call for more interaction among academics, practitioners, and regulators. In specific words, to urge practitioners and academics to now, more than before, partner to push on the course of good corporate governance mechanism, identifying governance gaps in practice and linking the academics through collaborative efforts to ensure stakeholders confidence in the reports and operations of the entities. Schilder [8] had pointed to the merit of cooperation between researchers and practitioners, when he writes that researchers may benefit from the strong networks that larger firms have in place ... Accounting firms ... may gain a better understanding of what audit research can contribute, and learn from its analysis. Also, while some researchers have reported that academic researchers have had limited impact on regulations or the policy-making process [9-10], there is the prospect for this to change in the future.

Finally, some important areas where research can help advance our knowledge and that are relevant for policy makers include: audit firm governance, corporate level of compliance on corporate governance code, public sector code of governance, the challenges in the adoption of not-for-profit governance code by such organizations in Nigeria, the challenges of whistle blowers and whistle blowing.

The remainder of this article is organized as follows. The second section discusses some important changes in the Nigerian corporate governance framework for entities. The third section discusses some key questions on the corporate governance practices. From these questions, the study derives a number of research opportunities tailored to the Nigerian setting but with global interest. The fourth section contains concluding observations.

\subsection{Changes in The Nigeria Corporate Governance Landscape}

In order to appreciate this section of the paper, the changes are grouped into five distinct eras. 


\subsubsection{Pre - 1990 Era}

Before 1990, the principal company law statute in Nigeria was company Act of 1968. It contains elaborate provisions regarding the running of companies in relation to the roles of the Board of Directors and the members in general meeting. Based on stakeholders' criticisms the law was amended in 1990 with little modifications.

\subsubsection{0 - 2002 Era}

This era saw the wake of the Companies and Allied Matters Act (CAMA). CAMA 1990 was product of a rigorous process championed by the Nigeria law reform commission. It contains a lot of innovative provisions such as provisions on greater and more effective participation in, and control of the affairs of a company through improved provisions in respect of meetings. It made provisions for greater accountability by directors. As at this time, the concept of corporate governance had not emerged as a distinct concept. However, some corporate challenges around the world during this era, brought the concept of corporate governance practices to the fore. This resulted in countries issuing corporate governance codes to address issues neither specifically nor sufficiently addressed by their respective company legislation.

\subsubsection{3 - 2010 Era}

In August 2003, the Bankers' Executives Committee developed the corporate governance code for banks. This was the first corporate governance code in Nigeria. The major weakness in the 2003 Bankers' Committee's code was that it was not issued by a regulator having been issued by a voluntary association of the chief executives of the banks in Nigeria. Thus, not much is known about the code. The code was predicated on eleven principles. In October 2003 the Securities and Exchange Commission (SEC) issued the code of best practices in corporate governance in Nigeria known as 2003 SEC Code. It was the first corporate governance code to be issued by any regulator in Nigeria. Secondly, it was applicable to all public companies registered in Nigeria.

In 2006, the Central Bank of Nigeria (CBN) issued its code of corporate governance for Banks in Nigeria post-consolidation [11]. Compliance with the provisions of this code is mandatory for all banks operating in Nigeria.

In 2008, following the reforms in the pension sector which gave rise to greater private sector involvement in Pension fund management, the National Pension Commission (PENCOM) issued the code of corporate governance for licensed pension operators [12]. The code covered pension fund administrators and custodians.

In 2009, the National Insurance Commission (NAICOM) issued the code of business ethic and principles on corporate governance for the insurance industry [13]. The code brought in some basic principles of good governance such as: proactive, responsible, responsive, accountable and committed Board/management; definite management succession plan; culture of compliance with rules and regulations; good knowledge about business and insurance matters with requisite experience; disclosure and transparency; and effective exercise of shareholders' rights.

The 2006, 2008 and 2009 industry-specific corporate governance codes, addressed corporate governance issues, peculiar to the respective sectors at the time of their issuance, which the 2003 SEC Code did not address. Furthermore, the SEC Code [14] lacked adequate provisions on other contemporary corporate governance issues. These include: independent directors, critical Board committee in relation to corporate governance, director's appointment, tenure, remuneration and evaluation, ensuring the independence of the external auditors, whistle blowing procedures, sustainability issues, general disclosure and transparency issues.

\subsubsection{1 - 2014 Era}

Based on these gaps, it was quite obvious that there was a need to update the 2003 SEC Code. Therefore, on $1^{\text {st }}$ of April 2011, the SEC issued the code of corporate governance in Nigeria which replaced the 2003 SEC Code. During this period, four regulators were active in the corporate 
governance scene. The code was expected to be the minimum standards expected of public companies in Nigeria. But, in that year, the Financial Reporting Council of Nigeria (FRCN) Act was enacted by the Federal government. This statute has far-reaching provisions regarding the operation of companies in Nigeria. The FRCN was given express jurisdiction over corporate governance.

In 2014, the CBN reviewed its 2006 code to include:

- Submission by financial institutions of quarterly report of compliance with the CBN Code within a specified deadline.

- Prescription of a minimum of five board members for discount houses, no two members of the same extended family shall occupy the positions of chairman and MD/CEO or Ex-director of a bank's subsidiary at the same time.

- CBN's approval must be granted before certain acts are done e.g increase in shareholding above 5\% approval of Board committees' charter, notification of review of whistle-blowing policy after 3 years, appointment or removal of Chief Compliance Officer or head of internal audit of financial institutions among others.

The discrepancies in the standards prescribed by the aforementioned corporate governance codes led corporate governance experts to recommend a harmonisation of the corporate governance codes which could be applicable in different sectors ${ }^{6}$.

\subsubsection{5 till date}

Based on the identified gap from the above era, the harmonized code called the National Code of Corporate Governance (2016 National Code cited in Komolafe, 2016) [15] which was expected to be operational in the $1^{\text {st }}$ quarter of 2015 was released on October 17, 2016. The code comes in 3 parts, which are; code of corporate governance for private sector, code of governance for not-for-profit entities and code of governance for the public sector. Section 23(g) and 45 provide for the establishment of a Directorate of corporate governance for the FRCN. Section 50 and 51 stipulate the objectives and functions of the Directorate of corporate governance which include:

$>$ To develop principles and practices of corporate governance.

$>$ Promote the highest standards of corporate governance.

$>$ Promote public awareness about corporate governance principles and practices.

$>$ Act as national coordinating body responsible for all matters pertaining to corporate governance.

$>$ Promote sound financial reporting and accountability based on true and fair financial statement duly audited by competent independent auditors.

$>$ Encourage sound systems of internal control to safeguard stakeholders' investment and assets of public interest entities.

$>$ Ensure that audit committees of public interest entities keep under review the scope of the audit.

$>$ Its cost effectiveness, the independence and objectivity of the auditors.

$>$ Issue corporate governance code and guidelines.

$>$ Provide assistance and guidance in respect of the adoption or institution of the code in order to fulfil its objectives.

$>$ Establish links with the regional and international institutions engaged in promoting corporate governance.

The corporate governance code for the private sector is mandatory while that of the not-forprofit entities will be operated on the "comply or Justify non-compliance" basis in a manner similar to United Kingdom's code. 
In terms of substance, the National code is similar in some respect with the other codes. However, in terms of control, management responsibilities, unified code, enforcement power and coverage the National code is innovative. The new code although suspended has the following concerns:

1. One set of Nigeria corporate governance code for all private entities;

2. The introduction of independent oversight and enforcement of corporate governance compliance;

3. Arrangements regarding oversight and enforcement responsibilities across the various entities (ie Private, public and not-for-profit) and the creation of FRCN committees to coordinate oversight and enforcement activities; and

4. The supremacy of the National code of corporate governance.

Each of these four areas will be discussed below, and the implications for research are included in the third section.

\section{One set of Nigeria corporate governance code for all private entities}

Section 23(g) and 45 of the Act that established the FRCN provide for the establishment of a Directorate of corporate governance. This action brought about the harmonized code of corporate governance in 2016. This would have had a major impact, as before this date, each sector or industry applied its corporate governance code. Upon release of the code, its provisions especially as it relates to the management of an entity were a deviation from other enabling laws like Companies and Allied Matters Act. The code was perceived as being capable of disrupting the management of companies and with the potential of increasing the cost of doing business in Nigeria [16]. Hence, it was suspended three weeks after its enactment.

\section{The Introduction of Independent Oversight and Enforcement of Corporate Governance Compliance}

Nigeria entities have no history of independent oversight and enforcement body. Both the accounting and audit scandals at the beginning of this century and the objective of developing an integrated Nigerian capital market were important forces leading to the introduction of oversight and enforcement. Oversight of financial reporting in Nigeria is conducted by securities regulators and professional bodies, while in the auditing area there is no clear cut. In general, there is still a high degree of variation regarding oversight models. For example, one source of variation concerns the powers and sanctions of oversight bodies and to what extent the profession and practitioners have a role in inspections.

\section{Arrangements Regarding Oversight and Enforcement Responsibilities Across the Various Entities (Private, Public and Not-For-Profit) and the Creation of FRCN Committees to Coordinate Oversight and Enforcement Activities}

The variation in format, powers, and sanctions of oversight across the three types of entities result in coordination problems for companies and audit firms that are active in more than one entity type. The dominant principle to solve these coordination problems is described by researchers as a 'National Code'. This principle implies that the regulator in Nigeria entities or audit firm has in principle the mandate to oversee that all entities or audit firm, and other regulators needed to rely on those oversight activities. However, there are information exchange arrangements that give FRCN possibilities to receive information on industry oversight activities. To facilitate the coordination and consistency of oversight activities, FRCN should liaise with other regulators internal and external in executing its oversight and enforcement functions.

\section{Supremacy of the National Code of Corporate Governance}

The National Code stipulates that its provision supersede all other sectoral codes (section 38.2). The Code in section 38.3, further stipulates that regulators may issue supplementary guideline on sector specific matters relating to corporate governance. However, where those sectoral codes conflict with the code, the provision of the code will prevail (section 38.4). There are many agitations 
on the above subsections of the Code. Some of these agitations are that the code suggests that the Council is a superior agency of government with supervisory duties over the other agencies like the Central Bank of Nigeria, the National Insurance Commission, National Pension Commission, and the Securities and Exchange Commission. They claimed that, these agencies were established by an Act of the National Assembly and that they have the statutory powers to make rules, guidelines for the smooth operation of the sector they regulate [16]. These and a lot of other debates of the supremacy of the FRCN and the defunct Nation Code seem to be an interesting ground for research.

\subsection{Contemporary Issues and Research Opportunities in Corporate Governance}

A review of thirty papers stored in google search engine showed that studies have been conducted in corporate governance in Nigeria but they majorly centered on:

1. Corporate performance and corporate governance: there are avalanche of studies on the impact of corporate governance on firm performance, especially banks [17-20].

2. Corporate governance and compliance level: some researchers focused on assessing the level of compliance by firms [7, 21, 22, 6, 23].

3. Earnings management and corporate governance: There is this assertion that corporate governance can be used to manipulate earnings of an organization. Thus, studies were conducted on the effect of corporate governance on earnings management [24-25].

4. Assessment of corporate governance quality: some researchers deemed it necessary to assess the quality of corporate governance using the various codes [26, 27].

5. Others: other researchers studied the issues and challenges of corporate governance [28]. Abiola [29] and Okolie [30] studied corporate governance and auditing while Akindele [31] looked at risk and corporate governance. Omankhanlen \& Mukoro [32] studied the capital market and corporate governance.

The consequences of the enactment and suspension of the National code of corporate governance code in Nigeria, one of the key issues is to improve corporate confidence and the strength and stability of the FRCN through a better research feedback approach to corporate governance. This leads to a number of questions that are and will continue to be pertinent in current and future discussions among academics, practitioners, regulators, and investors, not only in Nigeria but also in the rest of the world. This study formulates some of these questions using these in juxtaposition with the changes in the Nigerian setting referred to in the second section, to present some research opportunities tailored to the Nigerian environment.

\section{Unified Code of corporate governance}

We have entered an era of more government intervention in the regulation of corporate governance. The governance of an entity is a technical venture and the establishment of code of corporate governance is, therefore, mainly an industrial or sectoral activity with an important role for the body charged with governance. However, it was observed that pressure for a unified code of corporate governance has been raised by researchers. For example, there have been researches on the need to unify the different codes of corporate governance by a regulatory body $[6,23]$.

Based on the fact that proliferations of regulations are not a product of competitive market force, there is the need to address questions such as the following: how effective are these codes? Do the differences between the entities demand for different codes? What effect will these have on investors' perception? Having SEC code for listed companies and having CBN, NAICOM, and PENCOM codes, which one will the various entities comply with? What are the costs and benefits of enacting different codes? How can the differences between the different codes be checked? In Nigeria, a growing number of papers $[6,23]$ addressed the need for unified code of governance. However, there is the need to ascertain whether specific industry code or general code is required. This has not been researched yet. 
The recent Etisalat Nigeria saga, where the huge indebtedness to some Nigerian banks gives practical expression to the above calls for industrial specific code and especially for private entities not quoted on the floor of the Nigerian Stock Exchange (NSE). Okolo [1] observed that, since Etisalat was taken over in June 15, 2017, over $\$ 1.72$ billion (i.e. about N541.8billon) debt impasse by a consortium of Nigerian banks, not a few people have questioned the place of corporate governance in the manner the firm conducted its business. This experience left this study to adopt one of the questions raised by Okolo [1] which states: What is the attitude of Nigerian banks (majority if not all in this case are public quoted entities and are ironically governed by strong corporate governance codes by different regulatory authorities) to the observance of corporate governance by the companies they extend credit facilities to?

\section{Independent oversight and enforcement}

Research in the field of public oversight is emerging (e.g., [33-35]) but is mainly focused on the US. However, in Nigeria, there is no direct oversight function by regulators. There are no regulators reports on the level of compliance of corporate governance code except for those of individual researchers. In a study by Ogbechie and Koufopoulos [36], titled 'corporate governance and Board practices in the Nigeria banking industry', they reported that Nigerian banks have a high degree of compliance with the Central Bank of Nigeria code of corporate governance. Conversely, Onakoya, Ofoegbu and Fasanya [18] showed a low compliance rate by the banks listed on the Nigerian Stock Exchange. They evaluated the compliance rate over five years covering 2005 to 2009. In the area of compliance research, researchers have not yet assessed entities compliance level using the new code like $[36,18,7,22]$ did with the other codes. There is still the need to conduct further studies in this area and also to assess the compliance level of other sectors in relation to their codes. Studies should check whether regulatory authorities exert their oversight functions on the companies and whether the penalties meted for non-compliance are commensurate with the offences committed.

Consequent on the supremacy polemics, the need for research to help address the questions is more relevant now than ever: does the requirement of FRCN in sections 38(2-4) amount to superiority? What is wrong with the enactment of a body to oversee the duties of other sectoral regulators? What are the challenges and prospects of having an oversight and enforcement body over other regulatory bodies? Does Nigeria truly need a National code of corporate governance? What obtains in other parts of the world in this regard?

\section{Audit firm Code of Corporate Governance}

Auditors are essential to the governance chain of any entity. Only, three of the codes stipulated external auditors concern in its code (i.e. CBN, SEC and NAICOM Codes); but the codes were not in synch with the various requirements concerning external auditors. They tried to provide for rotation of auditors, appointment, how auditors should deal with clients, rendering of non-audit services to audit clients, employment restrictions, audit firm tenure, involvement of audit committee, other supervisor powers of regulators, and evaluation of audit partners. Based on the above, it is obvious that the code did not specify how and who should determine external auditor remuneration and also, at what point should the remuneration be determined?. These requirements and more are well defined by international best practices but, they are not clearly treated in these codes and where they exist, they are not explicit. Researcher can conduct studies to compare our requirements of these codes and those of international standards. Also, studies have not been done to check whether audit firms comply with these minimum standards; how and who should perform annual review of the performance of the external auditor because the review should serve as a basis for deciding to retain the external auditor or otherwise.

The audit firm itself needs to institute its governance code to coordinate its own corporate governance issues. The lack or none existence of such could be cited as a reason for the recent scandal involving KPMG in South Africa. Hence, empirical studies could address questions such as how corporate governance code affects auditor incentives and behaviour, the extent to which it affects audit quality, instituting the code of corporate governance for audit firms, and the effectiveness and credibility of the corporate governance code regulatory body. Further, research can help in assessing 
the most efficient and effective governance structure at the engagement level, on the one hand, and governance at the firm level and the governance of firm-wide procedures on the other hand. No much research in this area except for Abiola [29] who studied the importance of internal auditors in ensuring dependable performance in Nigeria banking industry through effective corporate governance system and Okolie [30] whose study evaluated whether corporate governance principles affect audit committee functions by ensuring that financial statements reflect the true financial position of companies.

\section{Public sector code and compliance level}

This will be an interesting area for further research because presently, the public sector does not have corporate governance code. This made the pronouncement of the National code a laudable one when it was initially released before it met its waterloo. However, the usual lack of willpower in the public sector was also experienced in that suspended National code; where it states that the public sector code will not be applicable immediately until an executive directive is secured from the Federal Government of Nigeria [37]. Researchers have a benchmark to work with [38]; to ascertain the merit and demerit of this section of the code, the strength and weakness of the code, the need for such a code in the public sector and the likely benefits. There is a need to check the oversight capacity of the public sector and the need to have a body to assess the overblown powers of government in order to satisfy the interest of its stakeholders as well.

\section{Adoption of Not-for-profit governance code by such organisations in Nigeria}

There have been some insinuations here and there that some of our NGOs are reckless. They lack coordination. The code for this sector is really a welcome development. Unfortunately, the code is nowhere. Researchers have a key role to play in any nation's development and their role here is to conduct research in this area to show or justify the need for Corporate Governance Code for not-forprofit entities. However, the uniqueness of this sector should not also be overlooked. Studies can be conducted to help streamline the defunct code.

\section{Conclusion}

In this paper, the researcher calls for studies in corporate governance in Nigeria. The researcher used the change in the Nigeria scenery to identify a number of research questions with National and global interests where Nigeria provides some unique natural experimental settings to address these questions. After the historical background, the proliferation of code of corporate governance in Nigeria was discussed. Since 2003, the different regulators generated their industry specific codes and studies have been calling for a National code. The dream was brought to reality in 2016 but for a short time. This short-lived reality still plays an important role in driving research.

The study concludes that some important areas where research can help advance our knowledge and can be informative for public policy debates include: the need for unified code of corporate governance; the need for independent oversight and enforcement; instituting the code of corporate governance for audit firms, how public oversight affects auditor incentives and behaviour, the extent to which it affects audit quality, and the effectiveness and credibility of the corporate governance code regulatory body; the need for public sector code of governance; the need for code of conduct for not-for-profit entities; and compliance rate by the different entities. This study hopes that this paper will propel researchers' interest in these areas.

\section{Acknowledgements}

Sincere appreciation to all those who critiqued this article during the Benson Idahosa University's Accounting conference held in November 2017. 


\section{References}

[1] E. Okolo, Corporate governance in Nigeria: Myths and realities, (2017). Available: www.allnewsandreports.com.

[2] A. Shleifer, R.W. Vishny, A survey of corporate governance, Journal of Finance. 52(2) (1997) 738.

[3] F. Alayande, Recession: ICSAN harps on corporate governance as solution, (2017). Available at https://www.lawyard.ng/recession-icsan-experts-harp-on-corporate-governance-as-solution/. Extracted28/11/2018.

[4] OECD, Corporate governance : Better corporate practices for higher growth, (2015). Available: www.oecd.org/policy-briefs/japan--better-corporate -practices-for-higher-growth.pdf

[5] P.E. Masouros, Corporate Governance and the Great Recession: An Alternative Explanation for Germany's Success in the Post-2008 World (January 30, 2014). ELIAMEP, Crisis Observatory, Research Paper No. 8, January 2014 - The Dovenschmidt Quarterly. 1 (2014). Doi: $10.2139 /$ ssrn. 2388611 .

[6] G.O. Demaki, Proliferation of codes of corporate governance in Nigeria and economic development, Business and Management Review. 1(6) (2011) 1-7.

[7] E.Y. Akinkoye, O.O. Olasanmi, Corporate governance practice and level of compliance among firms in Nigeria: Industry analysis, Journal of Business and Retail Management Research. 9(1) (2014).

[8] Schilder, A., Research opportunities in auditing in the European union. Accounting Horizons. 10(4) (2004) 98-108.

[9] J. Francis, What do we know about audit quality? The British Accounting Review. 36 (2004), 345-368

[10] J. Francis, A framework for understanding and researching audit quality, Auditing: A Journal of Practice \& Theory. 30(2) (2011) 125-152.

[11] Central Bank of Nigeria code, Code of corporate governance for Banks in Nigeria postconsolidation, (2006). Available: www.ecgi.org.

[12] PENCOM, Code of corporate governance for licensed Pension operators-PENCOM, (2008). Available at www.pencom.gov.ng $>$ CodeCorporate

[13] NAICOM, National insurance Commission Code of good corporate governance for the insurance industry in Nigeria, (2009). Available at https://www.naicom.gov.ng

[14] SEC, Code of corporate governance for public companies, (2011). Available: www.sec.gov.ng.

[15] B. Komolafe, National corporate governance code to be operational in 2016-FRC, (2016). Available: vanguardngr.com. Retrieved: 29 October, 2017.

[16] A. Akinkumi, Is the National code of corporate governance for private sectors far reaching (1)? (2016). Available: https://www.googleweblight.com. Retrieved: 29 October 2017.

[17] A. Onakoya, D. Ofoegbu, I. Fasanya, Corporate governance and bank performance: a pooled study of selected banks in Nigeria, (2012). Available: https://eujournal.org.

[18] E.A. Oghojafor et al., Poor corporate governance and its consequences on the Nigerian banking sector, Serbian Journal of Management. 5(2) (2010).

[19] R.O. Akingunola, O.A. Adekunle, O.A. Adedipe, Corporate governance and bank performance (post - banks consolidation), European Journal of Business and Social Sciences. 2(8) (2007) 89-111. 
[20] I. Okoi, S. Ocheni, J. Sani, The effects of corporate governance on the performance of commercial banks in Nigeria, International Journal of Public Administration and Management Research. 2(2) (2014) 219-234.

[21] E. Adegbite, Corporate governance regulation in Nigeria. Corporate Governance: The International Journal of Business in Society. 12(2) (2012) 257-276.

[22] A. Kunle, B. Adejugbe, A review of corporate governance codes and best practices in Nigeria, (2010). Available at www.iiste.org $>$ JLPG $>$ article $>$ download

[23] J.B. Marshall, Corporate governance practices: An overview of the evolution of corporate governance codes in Nigeria, International Journal of Business and Law Research. 3(3) (2015) 49-65.

[24] O.M. Uadiale, Earnings management and corporate governance in Nigeria, Research Journal of Finance and Accounting. 3(3) (2012) 1-10.

[25] U. Uwuigbe, D.S. Peter, A. Oyeniyi, The effects of corporate governance mechanisms on earnings management of listed firms in Nigeria, Accounting and Management Information Systems. 13(1) (2014) 159-174.

[26] J.G. Cohen, G. Krishnamoorthy, A.M. Wright, The Corporate Governance Mosaic and Financial Reporting Quality, Journal of Accounting Literature. 23 (2004) 15-36.

[27] N. Klai, A. Omri, Corporate Governance and Financial reporting Quality: The Case of Tunisian Firms, International Business Research. 4(1) (2011) 1-9.

[28] A.O. Garuba, G.O. Otomewe, Corporate Governance in the Nigerian Banking Industry: Issues and Challenges, African research review: An International Multidisciplinary Journal, Ethiopia. 9(2) (2015) 104-117.

[29] J. Abiola, Corporate Governance in Nigerian Banking Sector, British Journal of Arts and social Sciences. 5(1) (2012) 1-9.

[30] J.U. Okolie, Corporate governance and audit committee in Nigeria. Journal of Policy and Development Studies. 9(1) (2014) 226-233.

[31] R.I. Akindele, Risk management and corporate governance performance - empirical evidence from the Nigerian banking sector. IFE PsychologIA: An International Journal, 20(1) (2012) 103-120.

[32] M. Omankhanlen, Insider perceptions of insider trading and corporate governance at Nigerian banks. International Journal of Risk and Contingency Management. 1(2) (2012): DOI: $10.4018 / \mathrm{ijrcm} .2012040101$.

[33] G. Hilary, C. Lennox, The credibility of self-regulation: Evidence from the accounting profession's peer review program. Journal of Accounting and Economics. 40(1-3) (2005) 211229.

[34] C. Lennox, J. Pittman, Auditing the auditors: Evidence on the recent reforms to the external monitoring of audit firms. Journal of Accounting and Economics. 49(1-2) (2010) 84-103.

[35] M. DeFond, How should the auditors be audited? Comparing the PCAOB inspections with the AICPA peer reviews, Journal of Accounting and Economics. 49(1-2) (2009) 104-108.

[36] C. Ogbechie, D.N. Koufopoulos, Corporate governance and board practices in the Nigerian Banking industry, (2010). Available: at www.ibs.edu.ng

[37] Thisdayonline, Finally FRC unveils National code of corporate governance, October 18, 2016. Available: https://www.thisdaylive.com. Retrieved: 29 October, 2017.

[38] National code, Is the National code for private sectors far reaching? (2016) Available: https://www.googleweblight.com. 